\title{
KONSOLIDASI GERAKAN MILENIAL INDONESIA DALAM UPAYA \\ MEMENANGKAN PASANGAN PRABOWO - SANDIAGA UNO \\ DALAM PEMILIHAN UMUM PRESIDEN 2019 DI KABUPATEN SIDOARJO
}

\author{
Lailatul Fitriyah ${ }^{1}$, Dwi Windyastuti Budi Hendrarti ${ }^{2}$ \\ ${ }^{1}$ Departemen Ilmu Politik, Fakultas Ilmu Sosial dan Ilmu Politik, Universitas Airlangga \\ lailatulfitriyah571@gmail.com \\ ${ }^{2}$ Departemen Ilmu Politik, Fakultas Ilmu Sosial dan Ilmu Politik, Universitas Airlangga \\ dhendrarti_fisip@unair.ac.id
}

\begin{abstract}
This study aimed to determine the tendencies carried out by GMI Sidoarjo in the 2019 presidential election. GMI Sidoarjo is one of the community organizations that acts as a successful team winning the pair of candidates in the 2019 presidential election. This research is descriptive qualitative by using the theory of political participation from Samuel Huntington and Nelson. From the results of the study obtained several results, namely political participation carried out are collective, organized, legal and ineffective. Consolidation is done internally and externally. Then, the form of political participation in conducting elections is carried out with political discussion, outreach, campaigning and vote escort. The winning effort was unsuccessful, so the pair supported by the Indonesian Millennial Movement in Sidoarjo was defeated due to the lack of targeted support in fighting for votes in the 2019 presidential election.
\end{abstract}

Keywords: Political participation, millennial generation, political consolidation.

\section{PENDAHULUAN}

Generasi muda dengan tahun kelahiran 1980 sampai dengan 2000-an dapat disebut sebagai generasi milenial. Generasi ini memiliki kemampuan yang lebih dari generasi sebelumnya, terutama dibidang komunikasi. Generasi milenial berkomunikasi tanpa bertatap muka secara langsung, dan bisa melakukan komunikasi melalui aplikasi secara daring (online). Melalui kemajuan teknologi yang jauh lebih modern dari masa sebelumnya, pergaulan milenial memiliki cakupan yang lebih luas dibandingkan dengan generasi sebelumnya. Keikutsertaan milenial dalam berpartisipasi politik menjadi hal penting yang harus diperhatikan, hal ini dikarenakan sikap apatis milenial terhadap politik menjadikannya bersifat apolitis terhadap jalannya politik pada saat ini. Kecenderungan milenial bersifat apolitis dibuktikan oleh Hasanudin Ali (2018), di mana 70\% milenial cenderung apatis pada hal-hal yang bersifat politik. Milenial cenderung menyukai pemberitaan gaya hidup, musik, IT dan menonton film. kaum milenial cenderung menganggap politik hanya untuk mereka generasi tua. Mereka juga tidak peduli terhadap proses politik yang terjadi di negeri ini dan enggan untuk menjadi bagian di dalamnya. Berikut yang menyebabkan milenial apolitis menurut Efriza dan Yoyoh Rohaniah (2015:1) Tingkat ketidakpercayaan yang rendah. para pelaku politik di Indonesia sangat berambisi terhadap posisi tertentu, beberapa tindakan menjatuhkan lawan dan politik uang memperlihatkan watak politisi yang sebenarnya; (2) Kecewa, beberapa orang mungkin beranggapan bahwa semua janji yang diberikan oleh 
politisi akan dilaksanakan setelah mereka terpilih, namun kenyataannya banyak sekali politisi yang melupakan janji saat masa kampanye hal inilah yang menimbulkan kekecewaan; (3) Buruknya citra partai politik. Banyaknya pemberitaan tentang kasus para politikus yang terjerat korupsi, kolusi, dan nepotisme telah mengakar sejak dahulu dan tidak bisa dipungkiri lagi hal tersebut semakin memperburuk citra partai; dan (4) Banyaknya kasus politisi yang belum selesai. Terlalu banyaknya berita di media massa tentang politisi bermasalah secara berkelanjutan membuat masyarakat heboh karena beritanya tak kunjung usai hingga membuat publik bosan.

Berdasarkan pada keprihatinan keadaan ini, muncullah sebuah organisasi masyarakat yang bernama Gerakan Milenial Indonesia (GMI). Organisasi ini berdiri pada 1 Oktober 2018 dan bentuknya adalah komunitas yang menjadi wadah bagi anak muda untuk memanfaatkan potensi pada diri mereka dengan menyampaikan keluh kesah menjalani kehidupan dengan mendiskusikan penyelesaiannya. Dengan tujuan membuat perubahan kepada generasi muda zaman sekarang yang cenderung apatis untuk sadar dan melakukan perubahan dimulai dari diri sendiri. Organisasi ini tidak hanya sekedar sekelompok milenial yang menginginkan perubahan dalam memperbaiki kehidupan mereka saja, tetapi memiliki keinginan untuk mendorong milenial agar aktif berpolitik dan mempersuasi milenial lain. Sehingga milenial mampu berpikir kritis terhadap apa yang terjadi dengan bergabung dan mendukung agar tidak menjadi swing voters. Dijelaskan oleh Surbakti (1992) bahwa partisipasi politik adalah kegiatan warga negara untuk mempengaruhi dan ikut mempengaruhi segala proses politik yang terjadi.

Pada momen pemilihan umum presiden 2019 ini, GMI memanfaatkannya dengan mendukung pasangan Prabowo-Sandiaga Uno. Hal tersebut dilakukan dengan berpartisipasi secara aktif menjadi pendukung dan berusaha mengumpulkan lebih banyak massa untuk menjatuhkan pilihan pada paslon 02. Selain menginginkan perubahan dalam hal keadilan dan kemakmuran, GMI juga berusaha mengingatkan para elite penguasa dengan cara nya sendiri yakni melalui penolakan terhadap hal-hal yang merugikan milenial. Organisasi ini akhirnya menjadi wadah bagi milenial yang menginginkan perubahan dengan memperluas diskusi politik.

Penelitian ini dilakukan dengan tujuan untuk mengetahui bentuk-bentuk partisipasi yang diberikan organisasi GMI yang ikut berpartisipasi pada Pemilihan Umum Presiden 2019 di kabupaten Sidoarjo dan mengetahui bagaimana konsolidasi politik yang dilakukan. Dalam penelitian ini digunakan metode kualitatif dengan subjek penelitian meliputi empat orang yang memiliki kedudukan penting di GMI Sidoarjo dan Jakarta . Adapun analisis dilakukan dengan mengelompokkan data sehingga rumusan masalah dapat terjawab. Penelitian ini memiliki perbedaan dengan penelitian terdahulu mengenai partisipasi politik milenial. Seperti pada penelitian yang dilakukan oleh Arnadi (2012) yang menghasilkan kesimpulan bahwa faktor pembentukan sikap apatis mahasiswa di Universitas Lampung pada mahasiswa Ilmu politik dipengaruhi oleh keterlibatan mereka dalam sebuah partai atau organisasi politik tidak membuahkan hasil yang nyata bagi kehidupan mereka sehingga mereka enggan untuk kembali bergabung dalam organisasi politik. Pada penelitian kedua yang dilakukan oleh Aulia (2014) menyebutkan bahwa keadaan pemilih pemula dalam melaksanakan partisipasi politiknya mendapatkan 
beberapa kendala di antaranya karena mereka tidak mendapatkan pendidikan politik oleh partai politik karena desa Karangsari, Banyumas sulit dijangkau. Hal ini menyebabkan kurangnya kesadaran politik para pemilih pemula yang ditunjukkan oleh sedikitnya milenial yang datang pada pemungutan suara pada pilpres 2014. Pada penelitian ketiga yang dilakukan oleh Ahmad Asroni, et al (2013) menyatakan pada organisasi Islam sayap partai Golkar melakukan kegiatan melalui dakwah Islam dalam menjaga kerukunan simpatisan dan kader. Dan pada penelitian keempat yang dilakukan oleh Retnayu Prasetyanti (2017) tentang generasi milenial dan inovasi jejaring demokrasi teman Ahok dilakukan dengan mengembangkan media sosial untuk pengawasan pergerakan dalam melakukan dukungan. Keempat hasil penelitian di atas memiliki perbedaan dengan penelitian ini, di antaranya: (1) Subyek pada penelitian pertama merupakan milenial yang paham betul tentang keadaan politik tetapi enggan untuk menjadi bagian dari organisasi politik; (2) Subjek pada penelitian kedua adalah tentang kendala pemilih pemula yang tidak mendapat pendidikan politik dalam menghadapi pemilu yang menyebabkan susah terwujudnya partisipasi politik milenial; dan (3) Pada penelitian ketiga dan keempat menyebutkan kedua subjek adalah sama yaitu milenial, tetapi dalam menerapkan strategi pemenangan memiliki perbedaan.

Pada penelitian ini peneliti memilih subjek generasi milenial yang apatis untuk diajak bergabung menjadi bagian organisasi. Kemudian diberikan pendidikan politik secara intens untuk memahami kepentingan organisasi dan pasangan calon 02 yang mereka dukung dengan mengajak berpartisipasi aktif mulai dari menjadi anggota, menyusun strategi, memilih hingga mengawasi jalannya pemilu. Gerakan Milenial di Sidoarjo mengkonsolidasikan dirinya melalui internal dan eksternal, tidak hanya melalui jejaring media massa.

\section{KERANGKA TEORITIK}

\section{Partisipasi Politik}

Partisipasi politik adalah kegiatan dari warga negara yang bertindak sebagai individu-individu, yang memiliki maksud untuk mempengaruhi pembuatan keputusan oleh pemerintah. Partisipasi politik bersifat individu atau kolektif, terorganisir atau spontan, mantap atau sporadik, dilakukan secara damai atau kekerasan, legal atau ilegal, efektif atau tidak efektif. Secara umum, partisipasi politik merupakan kegiatan seseorang atau sekelompok orang untuk yang turut serta dan aktif dalam pelaksanaan politik, seperti memilih seorang pemimpin negara secara langsung, dan turun untuk mempengaruhi kebijakan pemerintah (Huntington \& Nelson, 1994). Bentuk partisipasi ini dilakukan dengan tindakan seperti memberikan suara dalam pemilihan umum, menjadi anggota dari kelompok kepentingan, menjadi anggota sebuah partai, menjadi relawan, mengadakan hubungan dengan pejabat pemerintah atau anggota parlemen dan lain sebagainya. Adanya partisipasi politik menyebabkan kapasitas individu semakin berkembang dalam mengubah nasibnya sendiri. Di negara yang demokratis, pemikiran yang mendasari konsep partisipasi politik berdasarkan pada kedaulatan yang ada di tangan rakyat yang pada pelaksanaanya melalui kegiatan pemilu. Dijelaskan bahwa partisipasi politik dapat terwujud dalam 
berbagai bentuk, yaitu: organization activity, contacting, lobbying, electroral activity, dan violence merupakan bentuk partisipasi politik untuk keperluan analisa ada manfaatnya untuk mendefinisikannya sebagai kategori tersendiri.

Dalam konteks organization activity, pada dasarnya setiap warga negara memiliki kebebasan dalam berkumpul, berserikat dan mengeluarkan pendapat. Dalam hal ini meliputi partisipasi dari individu ke dalam organisasi, baik menjadi anggota ataupun sebagai pemimpin yang berguna untuk mempengaruhi pengambilan keputusan yang dilakukan oleh pemerintah.

Dalam konteks contacting, meliputi upaya kelompok atau individu yang berusaha membangun jaringan dengan menghubungi pejabat daerah pemerintah guna mempengaruhi keputusan mereka. Hal tersebut dilakukan karena pejabat memiliki akses kekuasaan yang bisa dimanfaatkan untuk ikut serta mendukung pergerakan sebuah organisasi politik dan mendatangkan manfaat bagi mereka.

Dalam konteks lobbying, meliputi upaya dari sekelompok orang atau individu untuk menghubungi pimpinan politik dengan maksud mempengaruhi setiap keputusan yang mereka tentang meliputi suatu isu-isu politik. Melobi biasanya dilakukan agar seorang pimpinan politik mampu meyakini adanya suatu isu tentu ada cara penyelesaiannya.

Dalam konteks electroral activity, kegiatan ini biasa dilakukan dari awal menjadi bagian dari anggota organisasi politik kemudian mempersuasi orang lain untuk bergabung, mencari dukungan, melakukan kampanye, mengambil sikap memilih, mencari dana kampanye, memberikan suara dan yang terakhir mengawasi jalannya pemilihan umum.

Partisipasi politik adalah aspek penting dalam negara demokrasi, terutama saat menggunakan pendekatan behavioral (perilaku) dan post-behavioral (pasca tingkah laku). Partisipasi politik banyak dilakukan di negara-negara berkembang karena pasrtisipasi politiknya masih pada tahap pertumbuhan. Perbedaan jenis partisipasi menurut frekuensi dan intensitasnya di antaranya sebagai berikut : (1) Menduduki sebuah jabatan politik dan administrasi; (2) mencari jabatan politik dan administrasi; (3) Mencari beberapa anggota aktif dalam sebuah organisasi politik; (4) Menjadi anggota pasif dalam sebuah kelompok atau organisasi politik; (5) Menjadi anggota aktif dalam sebuah kelompok atau organisasi semi politik; (6) Menjadi anggota pasif dalam suatu kelompok atau organisasi semi politik; (7) Partisipasi dalam demonstrasi; (8) Partisipasi pada sebuah diskusi politik internal; dan (9) Partisipasi pada Pemilihan Umum. Adapun bentuk-bentuk partisipasi politik berdasarkan jumlah pelakunya dikategorikan menjadi dua yaitu partisipasi individual dan partisipasi kolektif (Surbakti, 1992).

Berdasarkan definisi dan penjelasannya, adanya aktivitas partisipasi politik termanifestasikan ke dalam kegiatan yang dilakukan secara sukarela yang dilakukan secara nyata oleh masyarakat biasa. Anggota masyarakat memiliki keinginan untuk turut serta mengambil andil dalam partisipasi politik karena segala keputusan yang diambil oleh pemerintah ini bersifat mengikat. Dengan kata lain, masyarakat percaya bahwa setiap keputusan pasti ada dampaknya, dampak inilah yang disebut dengan political efficacy (Budiarjo, 2008). 
Untuk membedakan apakah sebuah aktivitas meliputi partisipasi politik atau tidak Huntington dan Nelson serta Ramlan Surbakti memberikan batasan untuk menggunakan konsep partisipasi politik. Menurut Huntington dan Nelson, konsep partisipasi politik tentu memiliki beberapa aspek pada definisi ini: Pertama, partisipasi politik mencakup kegiatan-kegiatan perilaku politik yang dilakukan secara nyata tidak meliputi sikap-sikap. Kedua, yang menjadi perhatian adalah kegiatan yang dilakukan oleh warga negara preman. Ketiga, berfokus kepada kegiatan-kegiatan pokok saja yang menjadi pusat perhatian untuk mempengaruhi pemerintah. Keempat, mencakup seluruh kegiatan dengan maksud untuk mempengaruhi pemerintah. Kelima, mencakup kegiatan orang lain di luar pelaku partisipasi yang bermaksud mempengaruhi segala bentuk keputusan yang diambil pemerintah biasa disebut sebagai partisipasi politik yang di mobilisasikan.

Kebalikan dari adanya partisipasi politik adalah apatis. Di samping masyarakat yang aktif dalam suatu bentuk partisipasi atau lebih tentu ada sekelompok masyarakat yang tidak melibatkan diri dalam berbagai kegiatan politik dan tidak peduli dengan permasalahan negara. Sikap apatis inilah yang menjadi perhatian khusus oleh para ilmuwan terdahulu karena sikap acuh tak memberi fleksibilitas kepada sistem politik, berbanding terbalik dengan warga negara yang selalu aktif melibatkan diri dalam berbagai kegiatan politik.

\section{HASIL DAN PEMBAHASAN}

\section{Partisipasi politik Gerakan Milenial Indonesia di Sidoarjo}

Gerakan Milennial Indonesia (GMI) merupakan sebuah organisasi politik yang berdiri atas dasar kerisauan terhadap kaum milenial yang masih saja apatis terhadap proses politik bisa dilihat dari pemilihan umum presiden, masih ada yang golput karena tidak percaya terhadap kredibilitas pemimpin menjadi faktor utama maraknya golput di Indonesia. Pemilih yang berasal dari generasi milenial nilainya mencapai 40\% sampai dengan 45\% pada Pemilu 2019. Tetapi dari hasil tersebut jumlahnya lebih banyak milenial yang apatis terhadap politik. hal terebut sesuai dengan hasil penelitian yang dilakukan oleh Hasanudin Ali, founder sekaligus CEO Alvara Research Center (Hasanudin, 2018). Banyaknya organisasi politik muncul dengan membawa pengaruh pada masing-masing permasalahan untuk dicari jalan penyelesaiannya. GMI hadir untuk meminimalisir kelompok milenial yang berperan sebagai swing voters untuk diberikan arahan agar mereka mampu menentukan siapa sosok yang pantas memimpin negara ini. Sebagai organisasi baru, GMI hadir sebagai wadah untuk milenial berkumpul agar mampu menganalisis setiap pergerakan aktivitas politik di Indonesia. Dalam perjalanannya GMI Sidoarjo sama saja dengan GMI pusat yang dimulai dengan diskusi ringan mengenai situasi politik yang sedang terjadi saat ini. Banyaknya anggota yang bergabung memperlihatkan kemampuan organisasi ini dalam mempersuasi milenial. Organisasi GMI Sidoarjo memang belum cukup diketahui oleh masyarakat oleh sebab itu dilakukan upaya konsolidasi politik untuk membentuk tim yang solid untuk mendukung paslon 02 yang dilakukan secara internal dan eksternal. 
Sebagai sebuah organisasi politik, GMI Sidoarjo memiliki visi yakni "Milenial itu Cerdas Konstitusional Bukan Emosional" dan misi organisasi yakni "Memenangkan Prabowo-Sandi pada Pilpres 2019”. Adapun struktur organisasi dijabarkan pada struktur berikut:

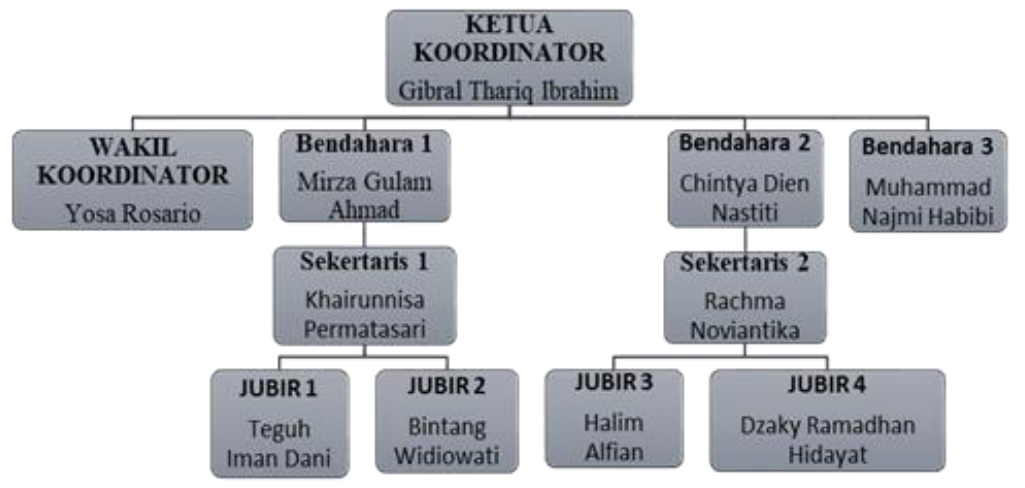

\section{Gambar 1. Struktur Organisasi GMI Sidoarjo}

Sumber: Dokumen Sekertaris GMI Sidoarjo tentang struktur organisasi GMI Sidoarjo

GMI Sidoarjo ini memiliki tujuan untuk memperkenalkan politik secara santai dengan cara diskusi politik ringan yang membahas seputar pemilu presiden 2019 yang akan digelar serentak dengan Pileg. GMI Sidoarjo berharap dengan adanya diskusi politik dan berbagai kampanye politik secara terbuka ini nantinya membuat masyarakat dan khususnya generasi milenial sadar betul bahwa turut menyalurkan hak suara itu sangat penting, menyangkut nasib kehidupan mereka lima tahun mendatang dalam menentukan sosok pemimpin. Pada organisasi ini juga mengadakan diskusi tentang pentingnya politik sehat dengan tidak terlibat dalam aksi saling menjatuhkan antar lawan, tapi beradu argumen secara positif dengan melihat data dan fakta yang terjadi di lapangan.

\section{Konsolidasi Internal GMI Sidoarjo}

Konsolidasi internal dapat dimaknai sebagai upaya penguatan yang dilakukan di dalam organisasi. Biasanya konsolidasi ini dilakukan dengan membentuk strategi untuk menciptakan tim yang solid.

Berikut beberapa cara yang dilakukan GMI yakni:

1. Mengadakan pertemuan rutin

GMI Sidoarjo melakukan konsolidasi secara internal dimulai dengan upaya penguatan organisasi secara menyeluruh, mulai dari pengurus inti hingga anggota. Seluruh anggota yang bergabung dalam GMI harus memiliki kesamaan visi dan misi yaitu memenangkan Prabowo-Sandiaga Uno dengan tujuan Adil dan makmur. Berikut merupakan langkah GMI Sidoarjo melakukan konsolidasi internal melalui pertemuan rutinnya :

a. Mengundang seluruh anggota dan pengurus inti untuk silaturahmi dan diskusi ringan;

b. Mengadakan event untuk milenial dengan sharing dengan pendiri GMI; 
c. Berdiskusi baik secara online dan bertatap muka (daring);

d. Menjadwalkan waktu untuk aktif berdiskusi dan menyusun agenda serta strategi pendekatan untuk turun sosialisasi ke masyarakat.

Konsolidasi internal dibutuhkan kerja nyata dari seluruh anggota organisasi untuk memperkuat organisasi. Sebagai wadah bagi kaum Millenial GMI Sidoarjo harus mampu menunjukkan perkembangan untuk memperkuat organisasi. Hal tersebut dapat dilakukan dengan mengelola semua potensi yang ada pada diri setiap anggota. Dengan meningkatkan peranan organisasi yang memberikan manfaat nyata bagi masyarakat, bukan hanya sebagai organisasi pendukung parpol semata.

2. Menyusun strategi pemenangan di lapangan, Strategi merupakan bagian dari perencanaan untuk menyukseskan tujuan melalui berbagai aktivitas yang dilakukan. Berbagai proses atau rangkaian kegiatan untuk mengambil sebuah keputusan yang bersifat menyeluruh beserta pelaksanaannya. Pembuatan strategi harus berasal dari pimpinan organisasi yang berkoordinasi dengan anggota dan kelompok-kelompok yang memiliki kepentingan sama. Berdasarkan wawancara di atas terlihat jelas bahwa strategi merupakan sebuah proses pengambilan keputusan yang dilakukan secara bersama secara menyeluruh. kemudian segala keputusan organisasi harus dilaksanakan dalam bentuk kegiatan yang pelaksanaannya terarah. Dalam hal ini GMI menggunakan dua strategi untuk pemenangan yaitu push marketing dan pass marketing.

\section{Konsolidasi Eksternal GMI Sidoarjo}

Konsolidasi Eksternal dapat dimaknai sebagai upaya penguatan yang dilakukan di luar lingkup organisasi. Berikut adalah cara GMI melakukan konsolidasi secara eksternal:

1. Menjangkau pemilih.

GMI Sidoarjo memiliki tujuan untuk memperkenalkan organisasi mereka, serta mensosialisasikan pasangan calon yang mereka dukung. Karena masyarakat sebagai pemilih berhak mengetahui sosok figur yang nanti akan mereka beri kepercayaan, maka adanya kunjungan ke pelosok kota Sidoarjo ini diharapkan memperkuat suara yang nanti didapatkan.

2. Mendatangi tokoh masyarakat berpengaruh.

Adanya aktivitas mencari dukungan kepada masyarakat dengan cara sosialisasi dan kampanye tentu akan efektif untuk menggalang dukungan guna memperoleh suara. GMI Sidoarjo juga menampung keluhan dan aspirasi masyarakat untuk disampaikan kepada pasangan PrabowoSandiaga Uno. Organisasi ini mendatangi sejumlah tokoh desa berpengaruh yang disegani oleh masyarakat sekitar. Seperti sesepuh di desa, ketua RW dan RT di beberapa wilayah.

3. Merawat basis suara

Banyaknya jumlah suara yang diharapkan oleh GMI Sidoarjo untuk memenangkan paslon 02 membuat organisasi ini memilih untuk merawat basis suara. Di mana pada tahun 2014 lalu Prabowo hanya mampu memenangkan 3 Kecamatan yakni Tarik, Buduran dan Jabon. Dengan 
mempertahankan suara yang didapatkan, GMI yakin wilayah tersebut akan menjadi daerah pemenangannya lagi.

4. Memperkuat kampanye secara door to door

Pendekatan kepada masyarakat juga dilakukan dengan kampanye secara door to door. Di mana kampanye dengan cara mendatangi pintu ke pintu dinilai lebih efektif dibandingkan dengan kampanye melalui pemasangan baliho. Karena dengan adanya kampanye ini masyarakat lebih nyaman karena bisa mengenal calon yang didukung lebih intens tanpa adanya campur tangan dari pihak lain. Karena GMI Sidoarjo yakin kampanye ini akan membuat pemilih yang belum punya pilihan jika dilakukan pendekatan akan tertarik mengikuti pilihan mereka, dan jika sudah punya pilihan bisa dilakukan persuasi sehingga mengubah calon yang nantinya akan dipilih.

5. Mendatangkan influencer

Aktivitas organisasi GMI yang menonjol sebagai bukti eksistensinya di kalangan masyarakat dibuktikan dengan mereka mengumpulkan massa pada kampanye akbar banyak dari kalangan masyarakat yang sadar akan sosialisasi yang telah diadakan sehingga mereka berkumpul. Dalam hal ini dapat terlihat dari banyaknya dukungan sebanyak 70.000 oleh masyarakat di Sidoarjo dan sekitarnya. Acara ini diagendakan oleh partai Gerindra bersama GMI Sidoarjo sebagai wujud dari rasa syukur akan dukungan yang mengalir dari masyarakat Sidoarjo. Acara ini diadakan di Stadion Gelora Delta Sidoarjo. Dalam kampanye akbar ini dihadiri sejumlah musisi dan politisi. Di antaranya Rhoma Irama, Nisa Sabyan, Al Ghazali, Ketua DPR Marzuki Ali, Juru Bicara BPN Prabowo-Sandi Gus Irvan Yusuf, Cucu pendiri Pondok Pesantren Gontor Ponorogo Gus Zulfikar, serta Ketua Umum DPP PAN Zukifli Hasan. Para musisi tanah air ini datang dengan undangan partai dan undangan dari anggota GMI yang memiliki koneksi dengan sejumlah penyanyi tersebut. Hal ini membuktikan Konsolidasi internal dan eksternal GMI Sidoarjo sudah cukup baik untuk membentuk solidaritas politik. Adanya aktivitas seperti ini dalam konteks politik Indonesia menjadi tahap baru dalam demokrasi.

6. Mengamankan suara yang diperoleh

Dalam mengawal jalannya pilpres 2019 ini GMI melakukan pengawalan dan pengawasan pada saat pemungutan dan perhitungan suara. Hal ini dilakukan agar tidak terjadi penyelewengan terhadap suara yang berhasil terkumpul. Dilihat dari kegiatan organisasi ini cenderung memiliki kekhawatiran terhadap hilangnya suara untuk paslon 02. GMI terus mengawal pada setiap kecamatan terutama pada daerah yang dianggap sebagai basis suara. Adanya partisipasi untuk mengawal jalannya Pemilu merupakan wujud nyata dari adanya revolusi mental rakyat yang sangat penting bagi berjalannya sistem demokrasi.

Berdasarkan konsep konsolidasi politik (Schmitter, 1993), menyebutkan bahwa konsolidasi merupakan sebuah proses penggabungan beberapa elemen politik untuk bekerja sama dan saling memfasilitasi proses politik yang berlangsung. Unsur yang terlibat dalam konsolidasi meliputi institusi politik atau lembaga politik, baik itu partai politik ataupun bukan, elite politik, kelompok kepentingan ataupun 
warga negara biasa. Konsolidasi politik menjadi hal yang harus dipertimbangkan oleh organisasi politik karena dengan melakukan konsolidasi maka akan mendapat kesepakatan bersama yang berisi tentang nilai politik. Dengan adanya konsolidasi politik akan mempertemukan elemen politik yang berbeda untuk saling mendukung dan memfasilitasi sebagai jalan untuk memperkuat organisasi politik. Di sisi lain Giovanni (Sartori, 1997) menyebutkan bahwa pluralisme politik dapat diidentifikasi melalui diversification of power yaitu waktu di mana distribusi kekuasaan politik menyebar pada sebuah kelompok-kelompok kepentingan yang ada dalam masyarakat dengan adanya kelompok kepentingan maka masyarakat dapat memetakan isu-isu dan dinamika politik yang terjadi ke dalam bentuk kepentingan yang saling berkonsensus bahkan pada akhirnya akan saling toleransi dengan tujuan yang sama yaini kehidupan yang seimbang.

Berikutnya adalah proses politik, yang mengacu pada proses di mana segala aturan dan prosedur sebagai warga negara diterapkan oleh lembaga-lembaga politik. Berpedoman pada Huntington, menyebutkan bahwa proses politik yang memiliki hubungan dengan institusionalisasi politik tentu berisi tuntutan serta dukungan politik dari masyarakat sebagai jalan untuk menyelesaikan permasalahan yang ada. (Huntington \& Nelson, 1994)

Berdasarkan dari sekian banyak pengertian dan teori-teori yang dikemukakan oleh para ahli, pada umumnya menjelaskan bahwa partisipasi politik merupakan wujud dari kebebasan setiap individu yang melibatkan hati nurani untuk menentukan sosok pemimpin yang mereka sukai. Bentuk-bentuk partisipasi politik di antaranya Organization activity, Contacting, Lobbying, dan Electroral activity dilakukan GMI Sidoarjo sebagai wujud dari keikutsertaan mereka dalam proses politik yang ada. Berbagai definisi partisipasi politik di atas dapat terwujud apabila GMI Sidoarjo melakukan upaya konsolidasi dengan pimpinan politik yang lain dengan memanfaatkan segala bentuk kekuasaan untuk memberikan sumbangsihnya ke dalam pergerakan pemenangan yang dilakukan GMI Sidoarjo untuk paslon 02. Dalam kaitanya dengan kelompok kepentingan, GMI Sidoarjo hadir sebagai wujud dari masyakat yang menuntut keadilan akan permasalahan politik yang muncul karena kebijakan yang dibuat pemerintah tidak sesuai dengan kehidupan mereka. Di mana mereka merasa tidak adil karena susahnya mencari pekerjaan, tidak terjaminnya kesehatan dan mahalnya bahan pokok. Oleh sebab itu, adanya pemimpin pada sentral organisasi politik sangat berpengaruh dalam melakukan upaya konsolidasi dan partisipasi politik baik dalam menyusun strategi hingga pelaksanaan kegiatan yang berhubungan dengan upaya pemenangan.

\section{SIMPULAN}

Generasi milenial menjadi apatis disebabkan oleh beberapa hal di antaranya: (1) Tingkat ketidakpercayaan yang rendah, (2) Kecewa, (3) Buruknya citra partai politik, (4) Banyaknya kasus politisi yang belum selesai. Sehingga muncul GMI sebagai organisasi politik yang menjadi wadah untuk memahami politik beserta kondisinya saat ini. GMI memanfaatkan momen pemilu untuk memberikan dukungannya kepada Prabowo-Sandiaga Uno. Alasan mereka memberikan dukungan 
adalah didasari dari pendiri GMI pusat yang sudah berafiliasi pada Prabowo sejak pemilu 2014. Kemudian memutuskan membuat pergerakan untuk mendukung paslon 02 dengan mengajak milenial melalui organisasi yang ada. Karena angka partisipasi milenial saat ini masih rendah, maka GMI berusaha mempengaruhi generasi milenial untuk berpartisipasi politik dan menjatuhkan pilihannya pada Prabowo-Sandi di Pemilu 2019.

Konsolidasi politik terjadi karena adanya kesepakatan dengan nilai-nilai politik yang bisa mendekatkan dan mempertemukan elemen-elemen politik menjadi kekuatan yang melebur menjadi satu tujuan. Contohnya : organisasi politik, partai politik dan massa. GMI Sidoarjo memiliki beberapa cara untuk melakukan konsolidasi yakni secara internal dan eksternal. Ada beberapa cara untuk mengkonsolidasikan organisasi secara internal . Pertama, melakukan pertemuan secara rutin dengan seluruh anggota . Pertemuan organisasi GMI rutin diadakan setiap akhir pekan, dimana pada pertemuan tersebut akan ada diskusi politik ringan. Kedua, menyusun strategi kampanye. Dan beberapa partisipasi politik yang dilakukan GMI Sidoarjo membuktikan peranan nyata mereka dalam mengumpulkan massa untuk mendukung Prabowo-Sandi.

Akan tetapi ketua GMI Sidoarjo tidak dapat mengkonsolidasikan kelompoknya dengan baik. Terbukti dari banyaknya followers Instagram yang bergabung hanya beberapa saja yang hadir di kegiatan organisasi. Kemudian pada strategi yang dipilih untuk pemenangan tidak efektif sehingga menyebabkan pasangan Prabowo-Sandi kalah pada Pemilu presiden tahun 2019 di Kabupaten Sidoarjo.

\section{DAFTAR PUSTAKA}

Ali H (2017) Milennial Nusantara. Jakarta: Gramedia Pustaka Utama.

Budiardjo M (2008) Dasar-Dasar Ilmu Politik. Jakarta: PT Gramedia Pustaka Utama.

Diamond L (2003) Developing Democracy toward Consolidation (Alih bahasa Tim Institute for Research and Empowerment (IRE). Yogyakarta: IRE Press. (Bibliography)

Guillermo O \& Phillipe CS (1993) Transisi Menuju Demokrasi. Jakarta: LP3ES. (Bibliography)

Huntington SP \& Nelson J (1994) Partisipasi Politik di Negara Berkembang. Jakarta: Rineka Cipta.

Nursal A (2004) Political Marketing: Strategi Memenangkan Pemilu. Jakarta: Gramedia Pustaka Utama. (Bibliography)

Ornstein NJ \& Elder S (1978) Interest Group, Lobbying and Policy Making. Congressional Quarterly Press. (Bibliography)

Rohaniah Y \& Efriza (2015) Pengantar Ilmu Politik, Kajian Mendasar Ilmu Politik. Malang: Intrans Publising.

Sartori G (1997) Understanding pluralism. Journal of Democracy, 8(4), 58-69.

Surbakti R (1992) Memahami Ilmu Politik. Jakarta: Gramedia Widiasarana Indonesia. 